\title{
PENYIMPANGAN PRILAKU ANAK-ANAK REMAJA SEKOLAH DI DESA WISATA KUTA LOMBOK (Studi Kasus Sebagai Langkah mengatasi Penyimpangan Moral)
}

\author{
Muhammad Saleh E \\ State Islamic University Mataram, Indonesia \\ Email: salehending25@gmail.com
}

\begin{abstract}
Pariwisata di desa Kuta Lombok Tengah menjadi sebuah momok dalam masyarakat, satu sisi bisa mendatangkan kesejahteraan hidup masyarakat setempat, di sisi yang lain kita menyaksikan fenomena sosial anak-anak remaja Sekolah yang dipengaruhi oleh dunia pariwisata itu sendiri, misalnya pencurian, pengrusakan, obat-obatan, alkohol, kekacauan, perkelahian, pelacuran hal ini dapat merusak moral masyarakat dan sangat berpeluang untuk menyebarkan penyakit. Menjadi tanggung jawab bersama dari Kepolisian, tokoh agama, tokoh adat untuk bersama-sama mengantisipasi dan menciptakan destinasi pariwisata halal untuk Lombok bumi seribu wajah keindahan.
\end{abstract}

\section{Keywords: Penyimpangan, Prilaku, Anak Sekolah, Pariwisata}

\section{A. PENDAHULUAN}

Kebijakan pemerintah dalam beberapa tahun terakhir ini dalam bidang pariwisata adalah mengembangkan pariwisata untuk memperbesar penerimaan devisa, memperluas kesempatan berusaha dan lapangan kerja, mendorong pembangunan daerah, meningkatkan kemakmuran dan kesejahtraan rakyat, memperkaya kebudayaan nasional dan tetap mempertahankan kepribadian bangsa dan tetap terpeliharanya nilai-nilai agama, dan pembangunan kepariwisataan juga diarahkan untuk mendorong pengembangan pemasaran produk nasional.

Pemerintah dalam hal ini beruusaha mengembangkan penyelenggaraan kepariwisataan ${ }^{1}$ lewat regulasi dengan menetapkan UU RI Nomor 9 Tahun 1990

\footnotetext{
1 Ada beberapa landasan hukum untuk penyelenggaraan pariwisata adalah; (a) TAP MPR RI No.II/MPR/1993 tentang GBHN menyatakan bahwa kebijakan pembangunan lima tahun keenam dalam bidang pariwisata meningkatkan dan mengembangkan parawisata untuk memperbesar penerimaan devisa, memperluas dan memeratakan kesempatan berusaha dan lapangan kerja, mendorong pembangunan daerah, meningkatkan kemakmuran dan kesejahtraan rakyat, memperkaya kebudayaan nasional dan tetap mempertahankan kepribadian bangsa dan tetap terpeliharanya nilai-nilai agama, dan pembangunan kepariwisataan juga diarahkan untuk mendorong pengembangan, pengarahan dan pemasaran produk nasional, (b) Atas dasar pertimbangan bahwa pengembangan kepariwisataan merupakan faktor potensial dalam usaha pembangunan di Indonesia secara menyeluruh dan merata perlu adanya pembinaan yang lebih terarah khususnya untuk memeratakan pendapatan dan menjamin perkembangan dan 
terhadap pembangunan obyek dan daya tarik wisata, mengusahakan obyek-obyek yang sudah ada maupun mengusahakan obyek-obyek baru, selaras dengan pembangunan sektor pariwisata, pemerintah tetap memelihara kelestarian dan mendorong upaya peningkatan mutu, mempertinggi drajat kemanusiaan dan mempertahankan nilai-nilai bangsa guna memperluas jati diri bangsa dalam rangka wawasan nusantara.

Dengan pesan itu maka pemerintah daerah NTB melakukan pembangunan baik sarana maupun prasarana yang mendukung pariwisata. Pembangunan sarana dan prasarana ini seperti yang ada di salah satu pulaunya yang dikenal dengan pulau Lombok.Pulau Lombok merupakan salah satu pulau tujuan kunjungan wisata yang ada di Indonesia selain pulau Bali dan tempat-tempat destinasi wisata yang lainnya. Pulau Lombok dikenal sebagai daerah yang memiliki keindahan alam, sehingga menjadi bulan-bulanan bagi para wisatawan untuk mencari ketenangan atau berlibur ke pulau tersebut.

Pulau Lombok merupakan salah satu pulau tujuan kunjungan wisata yang ada di Indonesia dan tempat-tempat destinasi wisata yang lainnya. Pulau Lombok dikenal sebagai daerah yang memiliki keindahan alam, sehingga menjadi bulanbulanan bagi para wisatawan untuk mencari ketenangan atau berlibur ke pulau tersebut. Namun sudah barang tentu wisatawan yang datang memiliki latar belakang budaya yang beraneka ragam dan berbeda dengan kepribadian penduduk setempat. Cepat atau lambat baik sengaja maupun tidak, ragam budaya tersebut dapat membawa dampak dalam kehidupan sosial-budaya anak remaja, termasuk diantaranya pola pikir atau perkembangan prilaku keagamaan mereka. Dampak buruk inilah yang akan meracuni pikiran anak-anak remaja sekolah, yang akan berakibat fatal terhadap mental spiritual mereka yang berakhir dengan terkikisnya nilai-nilai agama dalam diri mereka sehingga perkembangan keagamaan mereka pun akan sulit untuk menemukan arah menuju titik terang.

pembangunan daerah, maka dikeluarkan pembangunan (PP) nomor 24 Tahun 1979 mengenai penyerahan sebagian urusan pemerintahan dalam bidang kepariwisataan kepada daerah tingkat I/Provinsi, (c) ditetapkan peraturan daerah Provinsi Daerah Tingkat I Nusa Tenggara Barat nomor 9 tahun 1989 tentang Pembangunan Kawasan Pariwisata di pedoman dalam pembinaan, pengendalian pengawasan pembangunan kawasan pariwisata. 
Penyimpangan prilaku anak-anak remaja sekolah tidak hanya menjadi tugas pemerintah saja dalam mencari solusinya, tapi juga tugas semua pihak khususnnya keluarga, karena kalau keluarga baik dalam menyikapinya maka generasi akan bisa beradaptasi dengan situasi sosial yang melingkupinya. Keluarga merupakan unit sosial terkecil yang mampu memberikan fondasi primer bagi perkembangan mental spiritual dan perkembangan prilaku keagamaan anakanak remaja sekolah. Sedangkan lingkungan sekitar ikut memberikan nuansa pada perkembangan mental spiritual dan perkembangan prilaku keagamaan anak. Karena itu baik buruknya struktur keluarga dan masyarakat sekitar memberikan pengaruh baik atau buruknya pertumbuhan kepribadian anak. ${ }^{2}$

Dalam hal ini kecendrungan yang biasa di bawa oleh adanya warga negara asing apabila berkunjung untuk tujuan destinasi wisata adalah terjangkit perilaku delinkuen, yang merupakan produk konstitusi mental serta emosi yang sangat labil dan defektif, sebagai akibat dari proses pengkondisian lingkungan buruk terhadap pribadi remaja seperti pesta miras, perkelahian masa, dan obat-obatan terlarang, tindakan-tindakan immoral serta penyimpangan tingkah-laku lainnya akan merajalela di tengah kehidupan masyarakat seiring dengan perkembangan pariwisata tersebut. $^{3}$

Remaja sekolah seringkali dijadikan pembahasan oleh beberapa tokoh agama khususnya terkait dengan seputar penyimpangan-penyimpangan perilaku yang telah mereka lakukan yang dimana dari penyimpangan tersebut telah berdampak pada ketidaknyaman berbagai pihak, yang menjadi penyebabnya adalah kurangnya pemahaman dan tingkat kedewasaan remaja dan anak-anak terhadap makna filosofis dari agama. ${ }^{4}$

Bagaimanapun yang cukup rentan terkena dampak pariwisata khususnya dampak negatif pariwisata adalah para remaja. Hal ini terlihat jelas seiring dengan perubahan perilaku, dan sikap sehari-sehari mereka yang cendrung mengikuti pola-pola tingkah laku orang barat dan lebih regresif menjunjung tinggi hegemoni orang barat dalam segala hal yang terkadang tidak sesuai dengan

${ }^{2}$ Kartini kartono,Patologi sosial 2: Kenakalan Remaja (Jakarta:PT.Raja Grafindo Persada,2010),57.

${ }^{3}$ Kartini Kartono, Patologi Sosial 2, h.21-23.

${ }^{4}$ H. Munir, Wawancara Tanggal 8 April 2017 
syari'at dan tingkah laku masyarakat setempat sedangkan kulit bangsanya sendiri di biarkan kriput dan tak di anggap dalam keseharian.

Dari hasil research di desa Kuta Lombok Tengah ada kecendrungan penyimpangan prilaku tersebut karena di lokasi ini merupakan salah satu wilayah tujuan yang paling ramai dikunjungi dan cukup menarik perhatian para wisatawan baik yang domestik maupun wisatawan asing/mancanegara. Hal itulah yang menjadikan ketertarikan untuk menulis di desa ini.

\section{B. KONSEP PARIWISATA}

Hasil Penelitian ini mencoba mengamati dampak kepariwisataan terhadap anak-anak remaja sekolah, karena remajalah yang menerima secara langsung dampak dari pariwisata tersebut. Dimasa usia remaja cendrung mengikuti perubahan era globalisasi yang membawa kehidupan baru yang bersifat modern khususnya pariwisata yang melibatkan wisatawan asing seperti tourist dan excurtionist.

Pariwisata adalah suatu perjalanan yang dilakukan berkali-kali atau berputar dari satu tempat ketempat lain. ${ }^{5}$ Dari definisi di atas bahwa priwisata tidak hanya dilakukan di satu tempat saja tetapi juga di tempat yang lainnya yang dapat dijadikan sebagai satu daerah tujuan wisata yang mempunyai daya tarik wisata.

Pariwisata merupakan rangkaian kegiatan yang dilakukan oleh manusia baik secara perorangan maupun kelompok kedalam wilayah negara itu sendiri atau di negara lain dengan menggunakan kemudahan, jasa dan faktor penunjang lainnya yang diadakan oleh pemerintah atau masyarakat, agar dapat diwujudkan kegiatan wisata. $^{6}$

Jadi dapat disimpulkan bahwa pariwisata adalah suatu kegiatan manusia dengan fenomena-fenomena tertentu, sebagai akibat pergerakan, perpindahan atau berdiam, serta keluar masuknya orang-orang yang bukan mencari nafkah, bergerak dari suatu kota atau wilayah asalnya yang dapat membawa dinamika dalam kehidupan.

${ }^{5}$ Hilmi, Pengantar Kepariwisataan, (Bandung, PT.Angkasa,1994), h.9.

${ }^{6}$ Deparpostel, Paduan Sadar Wisata 1 dan 2. (Jakarta, Dirjen Pariwisata, 1994) h. 9 
Pembangunan pariwisata ditujukan untuk memberikan manfaat pada pemenuhan kebutuhan masyarakat dan peningkatan kualitas hidup dan kesejahteraan masyarakat. Tujuan ini sangat luhur dan positif, namun pada kenyataannya seringkali muncul berbagai permasalahan teknis meskipun sepertinya perencanaan yang dibuat telah dianggap sempurna.

Tujuan umum pembangunan pariwisata adalah untuk memperbesar penerimaan devisa, memperluas dan meratakan kesempatan berusaha dan lapangan kerja, mendorong pembangunan daerah, meningkatkan kesejahteraan dan kemakmuran rakyat, memperkaya kebudayaan dengan tetap mempertahankan kepribadian bangsa dan tetap terpeliharanya nilai-nilai agama.

Atas dasar pemahaman seperti itu, pemerintah dengan amanat rakyat melalui Ketetapan MPR mempertegas makna dan manfaat pembangunan pariwisata di Indonesia dengan arahan, tujuan dan kebijaksanaan, sebagaimana yang tertuang dalam GBHN Tahun 1976. Arahan pembangunan dan perkembangan pariwisata semakin di pertegas dalam GBHN Tahun 1988, yang bunyinya sebagai berikut:

1) Pembangunan kepariwisataan dilanjutkan dan ditingkatkan dengan pengembangan dan pendayagunaan sumber dan potensi kepariwisataan nasional menjadi kegiatan ekonomi yang dapat diandalkan untuk memperbesar penerimaan devisa negara, memperluas dan memeratakan kesempatan berusaha, dan lapangan kerja terutama untuk masyarakat setempat, mendorong pembangunan daerah, memperkenalkan alam dan nilai budaya bangsa. Dalam pembangunan kepariwisataan dilakukan secara menyeluruh dan terpadu dengan faktor-faktor pembangunan lainnya serta berbagai usaha kepariwisataan yang kecil, menengah dan besar agar dapat saling menunjang.

2) Pariwisata dalam negeri terus dikembangkan untuk memupuk rasa tanah air dan bangsa serta menanamkan jiwa, semangat dan nili-nilai luhur bangsa dalam rangka lebih memperkokoh persatuan dan kesatuan nasional disamping untuk meningkatkan kegiatan ekonomi. Usaha pembinaan dan pembangunan kepariwisataan dalam negeri ditujukan pula untuk meningkatkan kualitas, kebudayaan bangsa, memperkenalkan peninggalan sejarah serta keindahan dalam berbagai daerah diseluruh pelosok tanah air. Sehubungan dengan itu 
pelayanan dan penyelenggaraan pariwisata untuk masyarakat terutama remaja perlu ditingkatkan.

3) Dalam rangka pembangunan kepariwisataan perlu ditingkatkan langkahlangkah yang terarah dan terpadu dalam pengembangan obyek-obyek wisata promosi dan pemasarannya baik di dalam maupun di luar negeri. Selanjutnya ditingkatkan pendidikan dan pelatihan kepariwisataan, menyediakan sarana dan prasarana, mutu dan kelancaran pelayanan serta penyelenggaraan pariwisata.

4) Keadaan dan partisipasi masyarakat dalam kegiatan kepariwisataan perlu ditingkatkan melalui usaha-usaha penyuluhan dan pembinaan kelompokkelompok seni budaya, industri kerajinan dan usaha lain guna memelihara, memperkenalkan dan pengembangan kebudayaan bangsa serta tetap menjaga citra kepribadian dan martabat bangsa.

Terdapat banyak jenis daya tarik wisata yang dibagi dalam berbagai macam sistem klasifikasi dan daya tarik. Secara garis besar daya tarik wisata diklasifikasikan ke dalam tiga klasifikasi yakni; (1) daya tarik alam, (2) daya tarik budaya, dan (3) daya tarik buatan manusia. Akan tetapi pariwisata dapat pula dibagi dalam dua kategori yaitu; (1) obyek dan daya tarik wisata alam, dan (2) obyek dan daya tarik wisata sosial budaya.

Perencanaan dan pengelolaan obyek serta daya tarik wisata alam maupun sosial budaya harus berdasarkan pada kebijakan pembangunan nasional maupun regional. Jika kedua kebijakan rencana tersebut belum tersusun, tim perencanaan pengembangan obyek daya tarik wisata harus mampu mengasumsikan rencana kebijakan yang sesuai dengan areal yang bersangkautan. Para wisatawan sebagian besar tertarik pada daya tarik alam dan budaya pada daerah pariwisata yang mereka kunjungi karena masih bersifat alami dan bukan semata-mata buatan manusia.

\section{DAMPAK NEGATIF PARIWISATA}

Pembangunan pariwisata terkadang menjadi negatif, terutama bagi masyarakat remaja sekolah telah menjadi siksaan yang akan berpengaruh secara langsung, terhadap pandangan dari berbagai lapisan masyarakat, tentang pro dan kontra yang tidak akan berkesudahan. Polemik tentang pengembangan pariwisata hingga saat ini masih sulit dituntaskan selama pemahaman masyarakat luas belum 
menyentuh keakar tujuan pembangunan sebenarnya. Ada beberapa dampak negatif dari pariwisata di desa Kuta:

\section{Bidang Ekonomi dan Politik}

Dampak negatif dalam bidang ekonomi adalah harga barang atau jasa pelayanan menjadi naik karena kebanyakan pengunjung yang datang kesuatu kawasan atau daerah. Harga tanah juga ikut menjadi naik akibat sarana dan fasilitas wisata seperti pembangunan hotel, taman rekreasi, lapangan golf, dan lain sebagainya". 7 Dari pendapat di atas bahwa selain memberikan keuntungan pariwisata dapat memberikan dampak negatif, yaitu harga barang-barang menjadi naik dari sebelumnya dan berakibat bagi penduduk yang berekonomi lemah di Desa Kuta. ${ }^{8}$

Sedangkan dalam bidang politik, pariwisata juga berdampak negatif seperti di manfaatkan untuk melakukan subversi dan lafitra politik adalah lebih besar"9. Kasus seperti ini digunakan oleh calon kepala desa Kuta yang lalu melalui isu pariwisata dimungkinkan terjadinya penggulingan kekuasaan terhadap dirinya yang bersangkutan dengan jalan melemahkan kepercayaan atau kesetiaan kepada pemerintah dan penyusupan atau campur tangan (intervensi) dari pihak lawan politiknya. ${ }^{10}$

\section{Bidang sosial budaya}

Pengikisan terhadap kehidupan beragama, tradisi dan penodaan terhadap upacara serta tempat-tempat beribadah. Seni dan budaya suatu bangsa merupakan salah satu atraksi yang menjadi sasaran kunjungan wisatawan. Pengerusakan dan pencemaran terhadap peninggalan sejarah, dan budaya, tampilnya feodalisme, kemungkinan timbulnya konflik sosial, meningkatkan tindak pidana. ${ }^{11}$

Oleh karena itu pariwisata di desa Kuta yang tidak terarah memberikan dampak negatif terhadap daerah wisata tersebut, khususnya anak-anak remaja sekolah; (a) Penduduk khususnya para remaja sekolah suka mengikuti pola hidup parawisata yang tidak sesuai dengan budaya dan kepribadian budaya setempat, (b)

7 Deparpostel, Paduan Sadar Wisata 1 dan 2. (Jakarta, Dirjen Pariwisata, 1994) h. 17

8 Hasil Observasi 23 Juni 2017

${ }_{9}$ Deparpostel, Paduan Sadar Wisata 1 dan 2. .........,h.71.

10 Wawancara Alwanul Hamdi, Tanggal 24 Juli 2017

11 Deparpostel, Paduan Sadar Wisata 1 dan 2. ........,h.69 
Banyaknya wisatawan yang berkunjung kesuatu daerah, sering dimanfaatkan oleh orang-orang yang tidak bertanggung jawab untuk melakukan hal-hal yang tidak pantas seperti pemerasan, tindak perampokan, pengedaran barang-barang terlarang. ${ }^{12}$

Karena banyak pendatang yang berkunjung sebagai wisatawan, sering mempengaruhi penduduk setempat untuk tidak menghiraukan aturan-aturan agama ataupun tradisi yang ada di masyarakat. Secara tidak langsung ataupun langsung masyarakat setempat akan mudah terpengaruh khususnya para remaja, karena didukung faktor ekonomi dari para wisatawan itu sendiri.

\section{Bidang Lingkungan}

Pariwisata yang memanfaatkan keindahan alam tidak direncanakan dengan cara yang baik, kemungkinan terjadi degradasi keindahan alam yang besar sekali". ${ }^{13}$ Dari pendapat di atas, bahwa semua obyek wisata itu apabila tidak diatur terlebih dahulu tentang pelaksanaan pengembangannya, maka obyek-obyek tersebut akan mengalami penurunan kualitas atau kurang bermanfaat bagi kebutuhan manusia atau pembangkitan ekonomi rakyat.

Masalah-masalah yang timbul dalam pengembangan pariwisata jelas ada, dan itulah dampak negatif pariwisata di desa Kuta misalnya adalah anak anak remaja sekolah suka membuang sampah sembarangan, kurang bersih, berburuh burung, pembabatan hutan untuk keperluan kayu bakar, sehingga kepariwisataan itu tidak dikembangkan secara baik, maka pariwisata itu dapat menimbulkan masalah-masalah yang cukup besar dan mendasar sesuai dengan perkembangan selanjutnya. $^{14}$

\section{FAKTOR-FAKTOR YANG MEMPENGARUHI PRILAKU}

Masyarakat merupakan ajang hidup anak remaja disamping keluarga dan lingkungan sekolah. Dalam arti khusus, masyarakat merupakan kelompok manusia yang sudah cukup lama mengadakan interaksi sosial dalam kehidupan bersama yang diliputi oleh struktur serta sistem yang mengatur kehidupan.

\footnotetext{
12 M. Yusuf, Remaja Sekolah di Desa Kuta, wawancara tanggal 25 Juli 2017

13 Deparpostel, Paduan Sadar Wisata 1 dan 2. ........,h.68

14 Harun, Remaja Sekolah di Desa Kuta, wawancara 18 Juli 2017
} 
Disamping itu didalamnya terdapat nilai budaya yakni solidaritas sosial. Di dalam kehidupan masyarakat, biasanya terjadi interaksi sosial di antara individu dengan individu yang masing-masing memiliki kesadaran dan pengertian tentang hubungan timbal balik tersebut. Adapun beberapa faktor yang mempengaruhi prilaku remaja di antaranya:

\section{Kondisi keluarga}

Keluarga merupakan masyarakat ilmiah yang merupakan pergaulan antara anggotanya bersifat khas. Dalam lingkungan ini terletak dasar-dasar pendidikan. Disini pendidikan berlangsung dengan sendirinya tergantung dari tatanan pergaualan yang berlaku didalamnya, artinya tanpa harus diumumkan atau diharuskan terlebih dahulu agar diketahui dan di ikuti oleh seluruh keluarga, seperti penjelasan berikut ini:

"Sebagian besar anak dibesarkan oleh keluarga, disamping itu kenyataan menunjukkan bahwa di dalam keluargalah anak mendapatkan pendidikan dan pembinaan yang pertama kali. Pada dasarnya keluarga merupakan lingkungan kelompok sosial yang paling kecil, akan tetapi juga merupakan lingkungan yang paling dekat dan terkuat di dalam mendidik anak terutama bagi anakanak yang belum memasuki usia sekolah. ${ }^{15}$

Jadi menurut pendapat di atas, bahwa pembinaan akhlak pada seorang anak terpengaruh pada kondisi keluarganya. Dengan demikian berarti seluk beluk kehidupan keluarga memiliki pengaruh yang paling mendasar dalam perkembangan anak.

Untuk mencapai kehidupan moral yang baik dalam keluarga tidak dapat dipisahkan dari keyakinan beragama, karena nilai-nilai moral yang tegas, pasti dan tetap, tidak berubah karena keadaan, tempat dan waktu, adalah nilai yang bersumber pada agama. Karena itu dalam pembinaan generasi muda, petuah kehidupan moral dan agama itu harus sejalan dan mendapat perhatian yang serius. $^{16}$

Dalam pembinaan generasi muda itu, peranan orang tua sangat penting, karena pembinaan itu berarti pembinaan segala aspek dari kehidupan mereka, terutama pembinaan pribadi yang masih sejak si anak lahir, bahkan sejak dalam

15Sudarsono, Etika Islam Tentang Kenakalan Remaja (Jakarta:PT.Rineka Cipta,1989), h. 19.

16Nurseim, Wawancara tanggal 12 Juli 2017 
kandungan. Disamping itu perlu kita sadari bahwa pembinaan pribadi dan moral itu, terjadi melalui semua segi pengalaman hidup baik melalui penglihatan, pendengaran, dan perlakuan yang diterimanya. Maka semakin kecil umur si anak semakin banyak ia bergaul dengan ibunya dan semakin banyaklah ia menyerap pengalaman yang ikut membina pribadinya dari ibunya sendirinya, karena peranan orang tua sangat penting dalam generasi muda. ${ }^{17}$

Disamping itu, yang sangat menggelisahkan anak-anak remaja adalah tampaknya perbedaan antara nilai akhlak yang diajarkan berdasarkan nilai-nilai agama dengan kelakuan orang dalam masyarakat. Terutama yang sangat menggelisahkan remaja, apabila pertentangan itu terlihat dari orang tua, guru-guru di sekolah, pemimpin-pemimpin, dan tokoh-tokoh agama.

Dengan demikian semakin besar perbedaan antara nilai-nilai agama dan kelakuan orang yang dihargainya, akan semakin goncang jiwa remaja, sasaran utama dari kekecewaannya akan kepada tokoh-tokoh agama, karena mereka mengharapkan tokoh agama yang harus menjaga dan memperbaiki akhlak masyarakat. Banyak lagi faktor yang menggoncangkan jiwa remaja, seyogyanya guru agama dapat memahaminya, agar dapat menyelami jiwa remaja itu, lalu membawa mereka kepada ajaran agama, sehingga ajaran agama yang mereka dapat itu betul-betul dapat meredakan kegoncangan jiwa mereka. Hal itulah yang dapat mempengaruhi perkembangan baik buruknya jiwa dan prilaku seorang anak remaja yang masih membutuhkan kasih sayang orang tua.

\section{Kondisi Sekolah}

Ajang pendidikan kedua bagi anak-anak setelah keluarga adalah sekolah. Bagi bangsa Indonesia masa remaja merupakan masa pembinaan, penggemblengan terutama pada masa-masa permulaan. Dalam masa tersebut remaja pada umumnya duduk di bangku Sekolah Menengah Pertama (SMP) dan Sekolah Menengah Atas (SMA) atau yang sederajat. Dalam kenyataannya bukan hanya memiliki aspek sosiologi yang positif, akan tetapi juga membawa akibat lain yang memberi dorongan bagi anak remaja sekolah. ${ }^{18}$

17 Nurseim, Wawancara 17 Juni 2017

18 Wawancara, Lalu Fathurrahman, Tanggal 19 Juli 2017

\begin{tabular}{|c|c|c|c|c|c|} 
Jurnal & Volume & Nomor & Halaman & Mataram & ISSN \\
Ibtida'iy & 04 & 1 & $1-97$ & April 2019 & $2501-504 \mathrm{X}$
\end{tabular}




\section{Kondisi lingkungan masyarakat}

Masyarakat adalah suatu sub-sistem di dalam kehidupan yang ikut serta dalam pembentukan kepribadian, suasana yang ada di lingkungan masyarakat yaitu seperti terjadinya kesenjangan antara apa yang telah diajarkan kepada mereka (remaja) tentang moral atau akhlak yang baik dengan kenyataan akhlak sebagian dalam kehidupan sehari-hari. Menurut Nurseim dalam ajaran agama mereka diajarkan untuk tidak berjudi dan minum minuman keras, tetapi dalam masyarakat kenyataannya berbeda dengan apa yang diajarkan tersebut. Sehingga dengan adanya kesenjangan-kesenjangan ini lah para remaja atau generasi muda mengalami goncangan-goncangan yang membuat mereka menjadi bingung dan sulit menentukan sikap, yang akhirnya mempengaruhi kepribadian dan jiwa mereka. ${ }^{19}$

Seperti dijelaskan berikut ini:

"Kekacauan ekonomi, rumah tangga yang berantakan, ketidakpuasan dengan pelajaran dan pekerjaan, terjadinya diskriminasi tentang sesuatu, persaingan yang tidak adil, dengan persaingan yang menggunakan segala cara, korupsi, menyelenggarakan club-club malam, reklame dengan gambar-gambar yang tidak pantas dipandang mata pemuda, pergaulan di luar kebiasaan dan sebagainya, cukuplah kiranya dapat menimbulkan gangguan dan kesesatan pemuda yang jiwanya serba di dalam ketidaktentraman ${ }^{20}$.

Dari pendapat di atas, bahwa selain lingkungan keluarga, sekolah, juga terdapat faktor yang dapat mempengaruhi yaitu lingkungan masyarakat, karena masyarakat dalam kelompok pergaulan yang melibatkan berbagai hal yang dapat mempengaruhi jiwa para remaja.

\section{E. PROTEKSI PERILAKU ANAK SEKOLAH}

Salah jika menyatakan bahwa pariwisata adalah satu-satunya penyebab terjadinya beberapa atau semua perubahan, ketika orang-orang mengungkapkan ke majalah, koran atau film tentang negara lain, prubahan-prubahan dengan membawa tamu dan tuan rumah dalam hubungan yang sangat baik, jika kita dapat mengatakan bahwa perubahan ini adalah baik buruk. Ketika masyarakat tradisional mulai bersikap kebarat-baratan, beberapa golongan akan terluka

${ }^{19}$ Nurseim, wawancara tanggal 21 Juli 2017

20 Sudarsono, Etika Islam Tentang Kenakalan Remaja ......,h.31. 
sementara yang lainnya akan merasa beruntung, pariwisata mempercepat perubahan-perubahan ini.

Prilaku wisatawan di tempat tujuan wisata tercatat memberikan pengaruh pada masyarakat lokal. Ketika penduduk lokal berlomba mencari dan melayani para pengunjung yang datang, wisatawan dengan karakteristik yang berbeda perlakuannya dan memberikan standar kehidupan yang berbeda-beda pengaruh prilaku wisatawan mendorong masyarakat lokal untuk bekerja dan mengajar sesuatu yang mereka tidak punya, sesuatu yang baru dan tampak baik akan dikenalkan atau dilakukan wisatawan, akibatnya tidak jarang wisatawan diperlakukan berbeda dari kebiasaan penduduk lokal untuk menarik perhatian wisatawan, meskipun cara-cara tersebut bertentangan dengan nilai-nilai agama, karena mencari kekayaan dengan cara-cara yang tidak halal.

Secara ekonomi dalam mencoba mencari peluang perjalanan wisatawan, masyarakat pedesaan turut ambil bagian dengan bekerja dibidang jasa ditempattempat tujuan wisata, sehingga tidak sedikit diantara mereka yang meninggalkan kampung halamannya untuk pekerjaan ini. Hal ini dapat menjadi masalah dalam menjaga kebutuhan tenaga kerja dibidang pertanian. Pekerja migrasi dari desa ke kota dari satu negara ke negara lain adalah suatu dampak dari pariwisata.

Dampak lain dari pariwisata adalah ada aspek yang besar dari orang tua untuk para anak muda, sebagai akibat dari kegiatan kepariwisataan anak muda boleh meninggalkan rumah dan segera mendapatkan upah lebih dari orang tua mereka dengan cara bekerja di daerah-daerah tujuan wisata.

Merupakan suatu sugesti bahwa pariwisata membawa akibat pada perubahan kondisi moral masyarakat setempat seperti pelacuran, angka tindak kriminal meningkat, dan perjudian di tempat tujuan wisata, dan hal-hal tersebut kerap menimpa moralnya kaum remaja yang masih rawan dengan pengaruh para wisatawan tanpa bisa berpikir lebih panjang dan lebih baik.

Adapun kegiatan pariwisata memberi pengaruh pada:

1. Hubungan antara pariwisata dan kejahatan. Manusia yang membawa uang cendrung mengundang kejahatan dan pengaruh lainnya seperti perampokan, pencurian, pengrusakan, obat-obatan, alkohol, serta prilaku negatif lainnya. 
2. Perjudian di beberapa negara dan ini menjadi hiburan dan efek negatifnya lebih besar seperti kekacauan, perkelahian, dan pengrusakan.

3. Pelacuran atau seks, hal ini dapat merusak moral masyarakat dan sangat berpeluang untuk menyebarkan penyakit. ${ }^{21}$

Dengan demikian pariwisata yang banyak melibatkan wisatawan mancanegara yang membawa beranekaragam kebudayaan yang tidak sesuai dengan agama dalam mempengaruhi prilaku (akhlak) masyarakat khususnya para remaja masih sekolah, karena masa remaja adalah masa persaingan yang kuat baik dalam pergaulan, mode dan gaya. Dampak kepariwisataan dirasakan langsung oleh kaum remaja masih sekolah karena parawisatawan cendrung lebih senang bergaul dengan para remaja setempat yang berada di lokasi yang dikunjungi.

Pendek kata, dari manapun juga kita lihat bahaya yang mungkin terjadi dan melihat apabila kehidupan moral dan agama dalam masyarakat dibiarkan saja menjalar dan mempengaruhi generasi muda kita. Untuk mengatasi masalah yang cukup membahayakan itu perlu mengadakan saringan (filterisasi) atau seleksi (selectif) terhadap kebudayaan asing yang masuk agar unsur-unsur negatif dapat dihindarkan, agar pendidikan agama baik dalam keluarga, sekolah maupun masyarakat diintensifkan supaya kehidupan beragama dapat terjamin dan selanjutnya kehidupan moral yang baik dapat menjadi bagian pribadi bangsa kita, nilai-nilai moral yang pasti, yang terdapat dalam ajaran agama itu akan membantu setiap pribadi untuk mendapat ketenangan jiwa sehingga kegairahan untuk membangun itu ada dan perlu diadakan pendidikan khusus untuk orang dewasa dalam bidang kesehatan jiwa, supaya mereka dapat membantu dirinya sendiri dalam menghadapi kegoncangan jiwa serta terciptanya ketenangan dan kebahagiaan dalam hidup bermasyarakat serta perlu adanya biro-biro konsultasi untuk membantu orang-orang yang memerlukannya, baik untuk anak dan remaja, maupun untuk orang dewasa.

Dalam kegiatan pembinaan itu sebaiknya pemerintah dengan wewenang yang ada padanya mengambil tindakan dan langkah-langkah yang tegas dengan

21 Erwan Renaldi, Pelaku Bisnis Pariwisata, Wawancara 1 Juli 2017 
mengikut sertakan semua lembaga, para ulama, dan pemimpin masyarakat. Dengan demikian akan terbentuk generasi muda yang diinginkan dan dapat dijadikan sebagai generasi penerus dalam setiap pembangunan tanpa harus meninggalkan nilai-nilai islamiyah, sehingga adat istiadat, kebudayaan, dan kepercayaan terus dapat dikembangkan.

\section{F. KESIMPULAN}

Dari pembahasan di atas, maka dapat disimpulkan bahwa pariwisata dan terhadap prilaku remaja sekolah di desa kuta dengan perkembangan kasus pariwisata yang ada sedikit terkikis dan terkesan mengikuti budaya wisatawan asing yang dating. Untuk hal itu, keterlibatan dalam hal pembinaan kehidupan beragama remaja sekolah sangat perlu dilakukan walaupun terkontaminasi oleh budaya asing yang di konsumsi oleh sebagian masyarakat remaja sekolah khususnya di Desa Kuta. Tokoh agama, Tokoh adat, kepolisian dan tokoh masyarakat harus melakukan tanggung jawab yang serius untuk menganggapi perkembangan pariwisata yang membuat penyimpangan perilaku remaja sekolah tersebut sehingga dapat mengancam kestabilan kehidupan yang hormoni dalam dunia pariwisata.

\section{G. DAFTAR PUSTAKA}

Abdul Wahid dan muhammad irfan, 2001 perlindungan terhadap korban kekerasan seksual: PT Refika Aditama, Yogyakarta.

Chalik, 1992. Dasar-Dasar Pengetahuan Pariwisata. Jakarta: PT. Yayasan Bakti Darajat, Zakiah, 1999. Ilmu Jiwa Agama. Jakarta:PT. Bulan Bintang.

Deparpostel , Dirjen Pariwisata, 1994. Paduan Sadar Wisata 1 dan 2.Jakarta.

Erawan, I Nyoman,1994. Perencanaan Pariwisata.Jakarta: PT. Pradnya Paramita. Gamal Suwantoro,2004 Dasar-Dasar Pariwisata, Yogyakarta Andi.

Garis - Garis Besar Haluan Negara Tentang Undang - Undang Kepariwisataan, 1991.Jakarta.

Hilmi,1994. Pengantar Kepariwisataan. Bandung:PT. Angkasa.

Himpunan Peraturan Perundang - Undangan dalam Bidang Kepariwisataan, 1989, Jakarta.

I Gde Pitana dan Putu G. Gayatri. 2005 Sosiologi Pariwisata: CV. Andi Yogyakarta. 
Kartono, kartini, 2002. Patologi Sosial (Kenakalan Remaja). Jakarta:PT. Rosda Karya.

Mappiare, Andi, 1982. Psikologi Remaja. Jakarta:PT. Rineka Cipta.

Pendit,S.Nyoman,1987. Ilmu Pariwisata (Sebuah Pengantar Perdana). Jakarta: PT. Pradnya Paramita.

Phil. Janianton Damanik, 2013. Pariwisata Indonesia antara peluang dan tantangan: pustaka pelajar Yogjakarta.

Purwanto, Ngalim,1990. Prinsip - Prinsip dan Teknik Evaluasi Pengajaran. Bandung :Rosda Karya.

Radjasa mu'tasim dan Timbul haryono sunardi. 2013 Agama dan Pariwisata telaah atas transformasi keagamaan komunitas Muhammadiyah borobudur: Yogyakarta fakultas tarbiyah dan keguruan UIN sunan kalijaga, pustaka pelajar.

Rifai, Muhammad dan Aziz, Abdul, 2001. Aqidah Akhlak jilid 1. Semarang:CV. Wicaksana.

Sihite, Rhicart, 1996. Industri Kepariwisataan.Bandung:PT.Remaja Rosda Karya. Sudarsono, 1989, Etika Islam Tentang Kenakalan Remaja. Jakarta:PT. Rineka Cipta. 